\title{
Mid-depth calcareous contourites in the latest Cretaceous of Caravaca (Subbetic Zone, SE Spain). Origin and palaeohydrological significance
}

\author{
Javier Martín-Chivelet*, María Antonia Fregenal-Martínez, Beatriz Chacón \\ Departamento de Estratigrafia, Institute de Geología Económica (CSIC-UCM), Facultad de Ciencias Geológicas, \\ Universidad Complutense, 28040 Madrid, Spain
}

\begin{abstract}
Deep marine carbonates of Late Campanian to Early Maastrichtian age that crop out in the Subbetic Zone near Caravaca (SE Spain) contain a thick succession of $\mathrm{dm}$-scale levels of calcareous contourites, alternating with fine-grained pelagites/ hemipelagites. These contourites, characterised by an abundance and variety of traction structures, internal erosive surfaces and inverse and normal grading at various scales, were interpreted as having been deposited under the influence of relatively deep ocean currents. Based on these contourites, a new facies model is proposed.

The subsurface currents that generated the contourites of Caravaca were probably related to the broad circumglobal, equatorial current system, the strongest oceanic feature of Cretaceous times. These deposits were formed in the mid-depth $(200-600 \mathrm{~m})$, hemipelagic environments at the ancient southern margin of Iberia. This palaeogeographic setting was susceptible to the effects of these currents because of its position close to the narrowest oceanic passage, through which the broad equatorial current system flowed in the westernmost area of the Tethys Seaway. Regional uplift, related to the onset of convergence between Iberia and Africa, probably favoured the generation of the contourites during the Late Campanian to the Early Maastrichtian.
\end{abstract}

Keywords: Contourites; Palaeoceanography; Late Cretaceous; Caravaca; Betics; SE Spain

\section{Introduction}

Over the last few years, there have been several developments in discriminating depositional facies of contourites and their mechanisms of formation based on studies of modern deep-sea deposits (e.g., Stow et

\footnotetext{
* Corresponding author.

E-mail addresses: j.m.chivelet@geo.ucm.es (J. Martín-Chivelet), mariana@geo.ucm.es (M.A. Fregenal-Martínez), bchacon@geo.ucm.es (B. Chacón).
}

al., 1996; Stow and Faugères, 1993, 1998; Stow and Mayall, 2000a; Shanmugam, 2000). These papers, which are mainly the result of extensive deep ocean coring and seismic programmes, show that contourites are less rare in the modern record than previously thought, and also suggest that they are relatively abundant in ancient pelagic and hemipelagic sequences. Notwithstanding, only a few works have dealt in detail with ancient contourite deposits. Difficulty associated with their recognition has probably been the main cause of this oversight. However, economic 


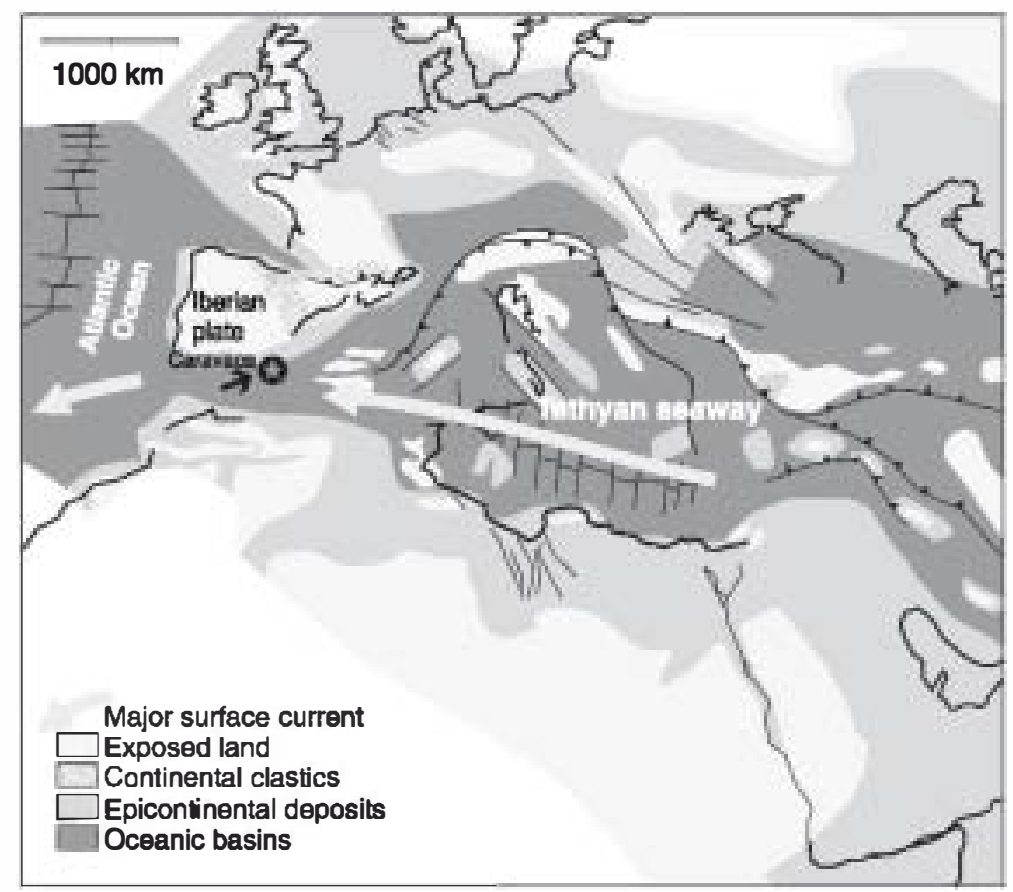

Fig. 2. Palaeogeographic reconstruction of the Tethys Seaway for the Maastrichtian (based on Philip and Floquet, 2000) showing the Betic continental margin (and the approximate position of the Caravaca outcrops) at the northem border of the gateway of the Tethys Seaway to the Cen Atlantic.

In this setting close to the Iberian microcontinent were deposited (e.g., Vera and Mølina, 1999) very

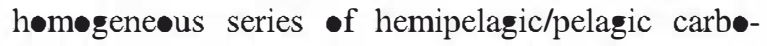
nates during most of the Late Cretaceous, while in the shallow parts of the margin, wide carbonate (and mixe carbonate-siliciclastic) platforms developed (e.g., Azema et al., 1979; Martín-Chivelet, 1992). Deposition on both platform and deeper environments were affected by regional major tectonic events that took place in response to changes in intraplate stresses (Martín-Chivelet, 1996). These tectonic changes had short time duration and led to changes in palaengegraphy, subsidence, fossils and type of sediments deposited (Martín-Chivelet, 1995).

The time span of the analysed sedimentary sequences (Late Campanian-Early Maastrichtian) corresponds to a period of relative tectonic quiescence at the margin, which lasted nearly all the Campanian and the Early Maastrichtian (i.e., about 13 million years according to Gradstein et al., 1995). It is bounde by two regional tectonic events (latest
Santonian-earliest Campanian and "mid" Maastrichtian in age, respectively), which resulted in the develøpment of two regional unconformities and their correlative conformities (Martín-Chivelet, 1995; Reicherter and Pletsch, 2000; Chacón and Martín-Chivelet, 2001).

\section{Stratigraphy}

Despite to the vast number of papers that refer to the KIT boundary in Caravaca (e.g., De Paøle et al., 1983; B॰h॰r et al., 1986; Canud• et al., 1991; R॰bin et al., 1991; Kaihø and Lamølda, 1999; Arz et al., 2000), •nly a few general stratigraphic studies of regional scope have considered Campanian and Løwer Maastrichtian deposits (e.g., Paquet, 1969; Van Veen, 1969; Høedemaeeker, 1973; Niet॰, 1997).

The sequence at Løma de la Sølana Hills is a $100-$ m-thick succession of white, fine grained limestones and marly limestones, which include abundant $\mathbf{d m}$ scale tabular intercalations of finely laminate calcar- 
enites. The whole unit corresponds to member $A$ of the Jorquera Formation in the sense of Van Veen (1969) (Fig. 2), thus being included in the middle part of the Quipar-Jørquera Formation in the sense $\bullet$ Vera et al. (1982).

The unit conformably rests on the hemipelagic carbønates of the Quipar Førmation (sensu Van Veen, 1969) and is overlain by a distinct unit of distinctively greenish grey hemipelagic marls (Member B of the Jorquera Formation) of Late Maastrichtian to Palecene age. Transition from the underlying unit is gradational and marke by a progressive increase in the number and thickness of intercalations of finely laminate calcarenite levels (herein interpreted as contourites). On the contrary, the contact with the -verlying marly unit is much more abrupt, reflecting a major pale ge graphic change caused by the regiønal tectonic event of mid-Maastrichtian age (e.g., Chacón and Martín-Chivelet, 2001; Chacón, 2002).

To precisely date the rocks and refine the agedating propese by Van Veen (1969), a biøchronøstratigraphic analysis, based on planktic foraminifera, was undertaken. The uppermest section of member A yielded the following indicative taxa: Contusotruncana walfischensis (Todd, 1970), Gansserina gansseri (B•lli, 1951), Globotruncana aegyptiaca (Nakkady, 1950), Globotruncanita angulata (Tilev, 1951), Planoglobulina acervudinoides (Egger, 1899), Plummerita reicheli (Bronnimann, 1952), Rugoglobigerina hexacamerata (Bronnimann, 1952) and Rugoglobigerina scotti (Bronnimann, 1952). This fossil assemblage characterises the middle part of the $G$.

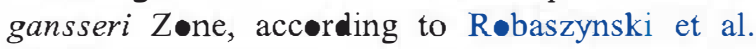
(2000), and corresponds to the lower Maastrichtian (Hardenbel et al., 1998). The gløbotruncanid assemblage obtained from the lowermost levels of the member $\mathrm{A}$ is rather poor and precludes its assignation to any biøzone. The very top of the underlying unit (Quipar Formation) yielded Globotruncanita calcarata (Cushman, 1927), a species that defines a biozone ranging in age from the late Middle Campanian to the early Late Campanian.

Comparable sequences with deposits of similar age and interpreted as contourites have als been found by the authørs in several $\bullet$ utcrøps of surrøunding areas $\bullet$ the Betics (e.g., Alicante-Jijona area, in the eastern Prebetic domain, Chacón, 2002). However, the con-

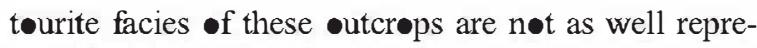
sented as in the Caravaca area.

\section{Sedimentology}

Tw• main, vertically alternating facies assøciations were identified in the member $A$ of the Jorquera Formation (Fig. 3). The first consists of hemipelagites, and is clearly dominant throughout the vertical succession (more than $60 \%$ of the total thickness). The second association, which constitutes less than the $40 \%$ of the succession, is interpreted as contourite

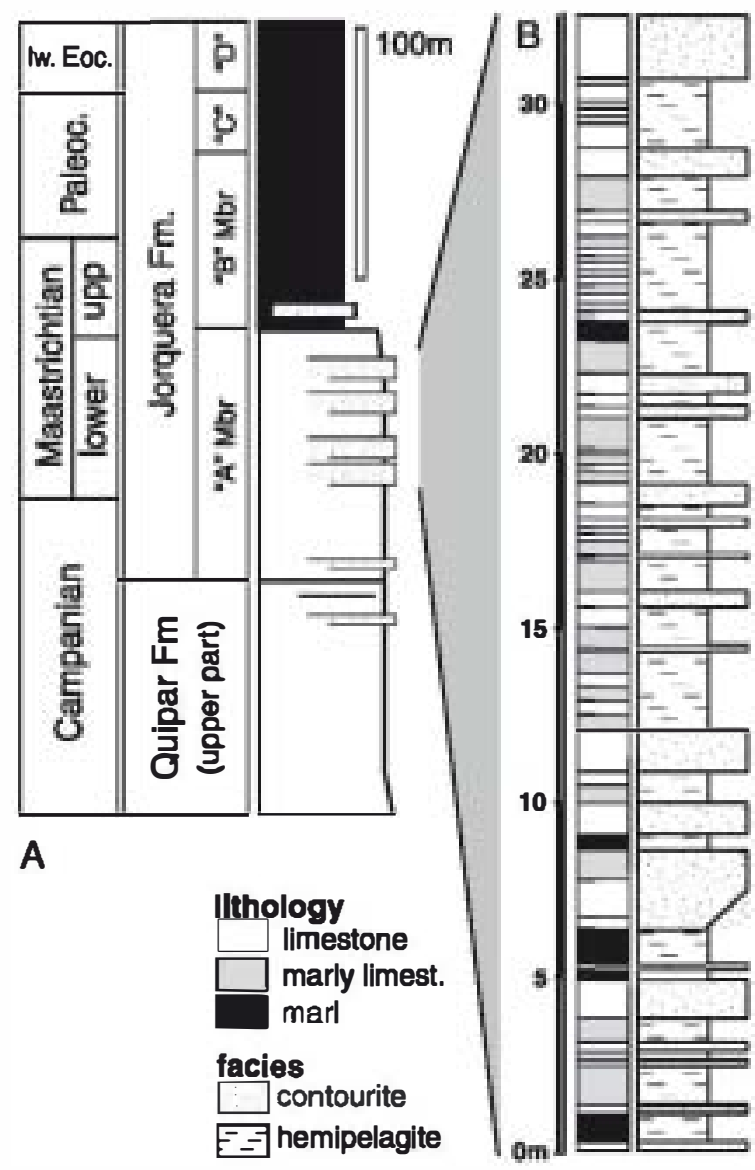

Fig. 3. (A) Latest Cretaceous-Early Palaeogene stratigraphy of the Caravaca area. Formation names and informal members were adopted from Van Veen, 1969. Ages according to Chacón (unpublished data). (B) Detailed section of the stratigraphic interval analysed where contourite and hemipelagite facies were separated. 
facies, consists of sediments dep॰sited, or significantly reworked, by deep marine currents.

\subsection{Hemipelagites}

The hemipelagites consist of an alternation of limestones (fine-grained wackestones) and marly limestønes (fine-grained wackestones with a variable proportion of fine grained terrigenous material) (Fig. $4 \mathrm{~A}$ ), arranged in thin to medium-thick (several centimetres to a few decimetres), often poorly defined, beds. These facies characterise typical deep marine carbonate sedimentation due to the slow and relatively steady fallout of biøgenic debris generated mainly in the upper part of the water column, and a variable, but always løw, input of fine terrigenøus material, probably transperted by winds or in suspension as plumes from the land. Bioturbation is frequent but moderate, and Chondrites and Zoophy$\cos$ (Fig. 4B) are the most common ichno-genera. Although Zoophycos and Chondrites have $\bullet$ ften been described in oxygen poor, organic matter-rich facies, their eccurrence does not seem to imply an oxygendepleted water/sediment interface (Bromley and Ekdale, 1984; Savrda, 1992). This pøint agrees with the presence of fossils of stenotopic organisms, such as inoceramids and echinøids, pøinting to normal salinity and exygenation conditions during depesition. The microfossil compønent includes abundant gløbotruncanids, calcisphaerulids and some deep-water benthic foraminifera, which appear randomly distributed and show ne evidence of reworking or sorting. This suggests minor or no current influence on depesition.

The benthic foraminifera assemblage-Gaudryina pyramidata (Cushman, 1926); Lenticulina sp.; Marssonella oxycona (Reuss, 1860); Oridorsalis sp.; Reus-

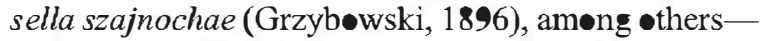
points to an upper bathyal palae-waterdepth, i.e., between 200 and $600 \mathrm{~m}$ (Van Morkhoven et al., 1986). Hemipelagic deposits from the uppermost part -f the underlying Quipar Formation have yielded a richer benthic assemblage with $G$. pyramidata (Cushman, 1926), Gavelinella becariiformis (White, 1928), Lenticulina sp., Oridorsalis sp., Quadrimorphina sp., R. szajnochae (Grzybowski, 1896) and Stensioina pommerana (Brotzen, 1940), which confirms this bathymetric interpretation.

The presence of alternating decimetre-scale limestønes and marly limestones suggests a high-frequency cyclicity recorded throughout the hemipelagites that is not observed where abundant contourite deposits •ccur (Fig. 4A). This type of cyclicity is a pervasive feature of similar hemipelagic facies in the
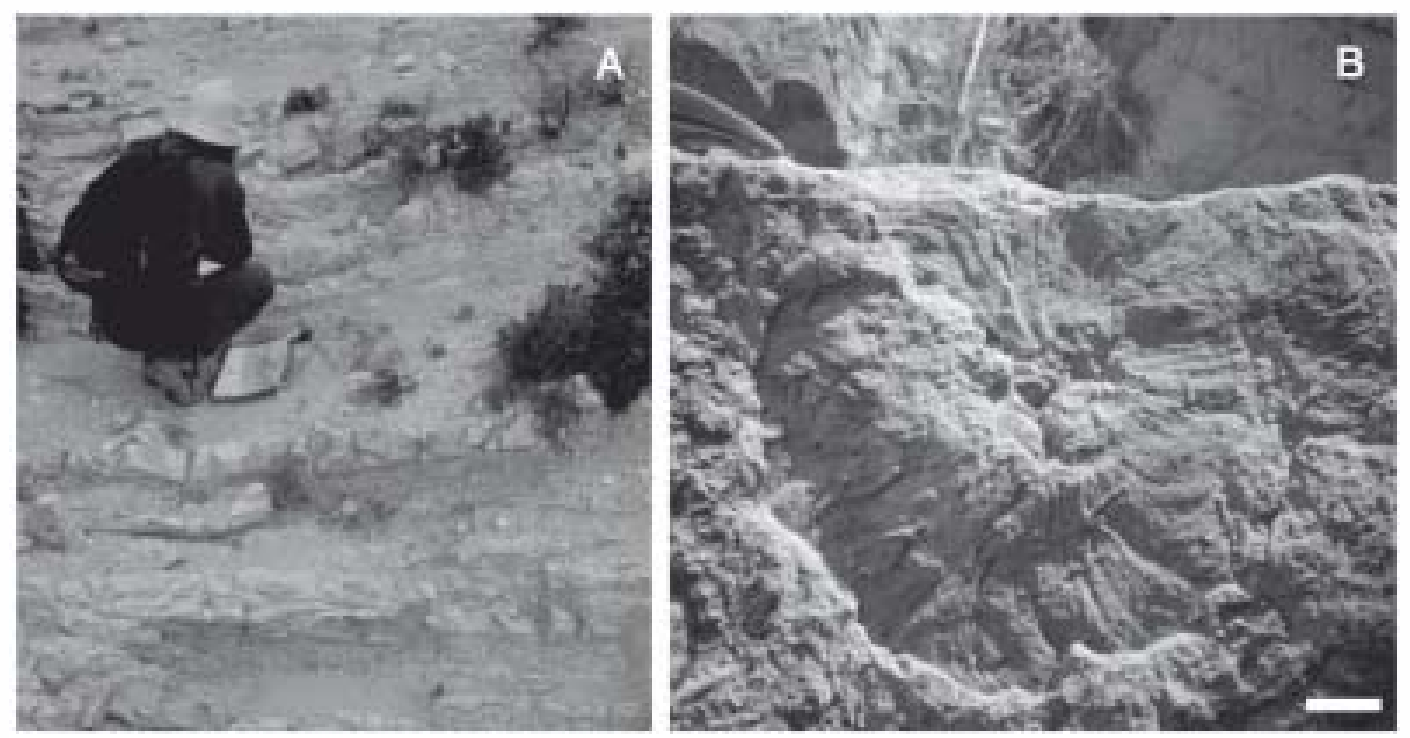

Fig. 4. Hemipelagite facies. (A) Typical rhythmic arrangement of limestones and marly limestones on the outcrop scale. (B) Detail of a Zœphyces structure within these facies (scale bar: $5 \mathrm{~cm}$ ). 
underlying Quipar Formation, as well as in cøeval sediments in other areas in the basin. It has been interpreted to be related to climate changes controlled by Milank $\bullet$ vitch orbital cycles (e.g., Vera and M•lina, 1999; Chacón and Martín-Chivelet, 2001).

\subsection{Contourites}

Cøntourites appear as stratified, tabular, vertically isølated beds $0.05-1.6 \mathrm{~m}$ thick (Fig. 5A). The base and top of each contourite bed are sharp, and mark the change from, or inte, the hemipelagic facies. The base is $\bullet$ ften markedly erosive and can show scour cast structures. Flute casts are a few millimetres deep and is late U-shaped løngitudinal scour casts resemble gutter cast morphølogies, but are smaller than the usual gutter structures. Flute casts are massive whereas longitudinal scour marks are filled with cross- laminate calcarenites. In contrast, the tops are never erosive and are usually defined by a flat, ripple-free

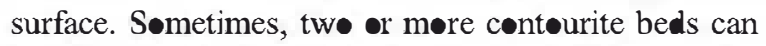
be amalgamated, and are thus separated by erosive surfaces.

Contourites are formed by very fine to medium sand-grained calcarenites which can occasionally reach a larger grain size. Texturally, they are carbonate grainstones to packstones, with usually less than $5 \%$ of siliciclastic grains of silt to fine sand size. Bi॰clastic material is dominant and consists of highly reworked and fragmented tests of the same organisms that appear in the hemipelagites (planktic foraminifera, a few deep water benthic foraminifera and calcisphaerulids, as well as calcite prisms arising from the break up of inoceramid shells). The bioclasts are mixed with abundant subrounded to angular intraclasts of micritic material similar to that predominating in the hemipelagic facies.
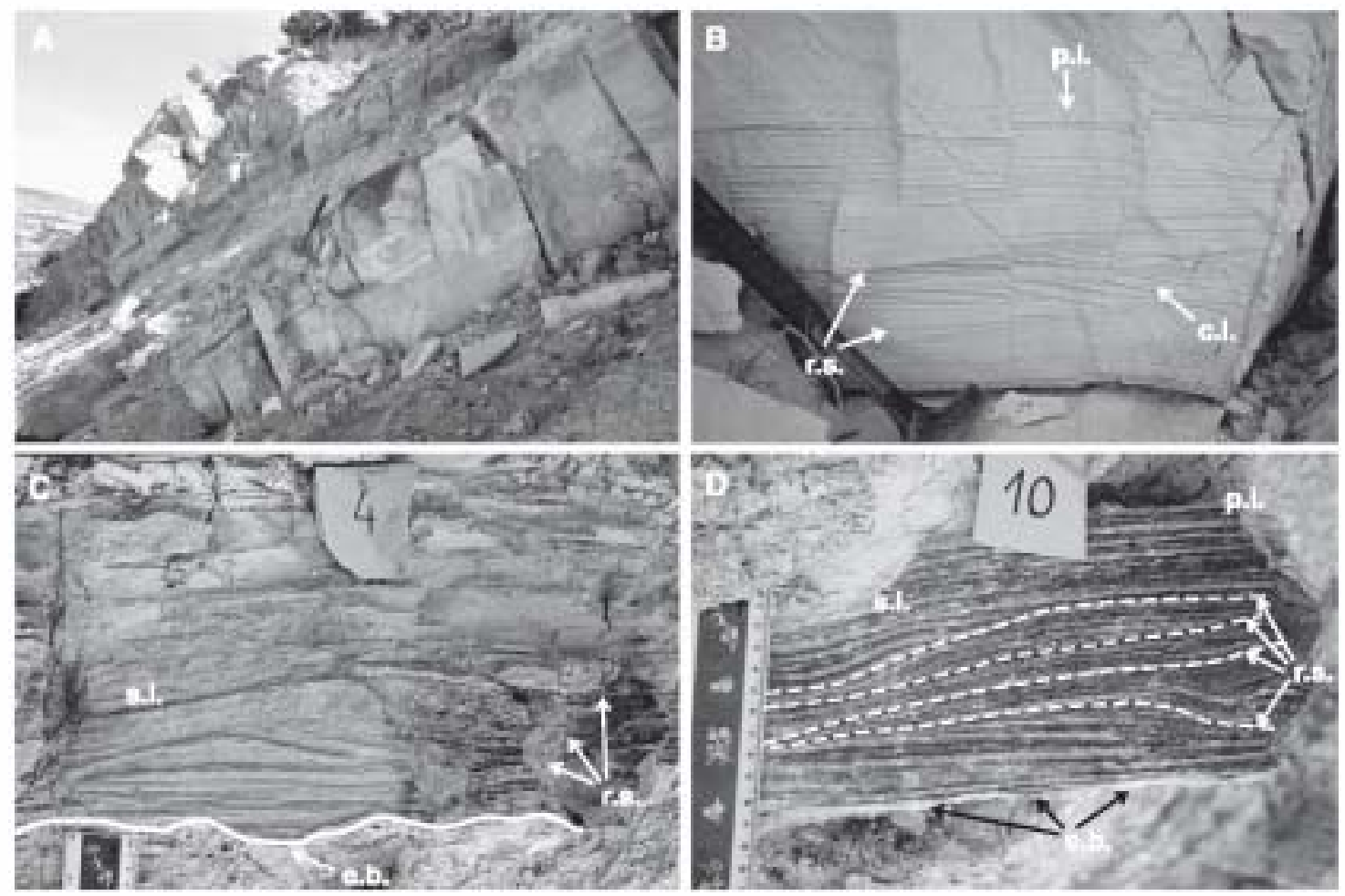

Fig. 5. Examples of contourite facies in the "A" member of the Jorquera Formation (Lower Maastrichtian). (A) Outcrop feature of $d m$ to $m$ scale contourite beds interbedded with less competent hemipelagic facies. See hammer for scale. (B to D) Details of contourite facies showing the most typical sedimentary suctures and their spatial distribution (e.b.: erosive basal surface; r.s.: intemal reactivation surfaces, usually involving erosion; c.l.: cross lamination; s.l.: sinusoidal lamination; p.l.: parallel lamination). Scale in $\mathrm{cm}$. 
Contourite beds are characterised by a defined vertical distribution sequence of both sedimentary structures and grain size (Fig. 6). Vertical grain size variations are observed at different scales. Both normal and reverse gradings are present within each contourite bed, althøugh pøsitive grading predominates. Maximum grain sizes are commonly found in the lower half of each level, but not necessarily at the base. Thereafter, it is common to observe an increase in grain size from the base to a certain level located a few centimetres above it, and a slight and gradual decrease from this level to the top of the bed. According to the observed sedimentary structures, most contourite beds can be roughly divided into two distinct intervals:

(1) A lower interval, which may represent a third to as much as over half the entire bed, characterised by the dominance of cross lamination, produced by the migration of ripples under the influence of a tractive current. Larger bedforms are only $\bullet$ ccasionally $\bullet$ bserved. Reactivation and slightly erosive surfaces are alsø frequent in this interval. Within this lower part, a

\section{Facies model}

(contourite)

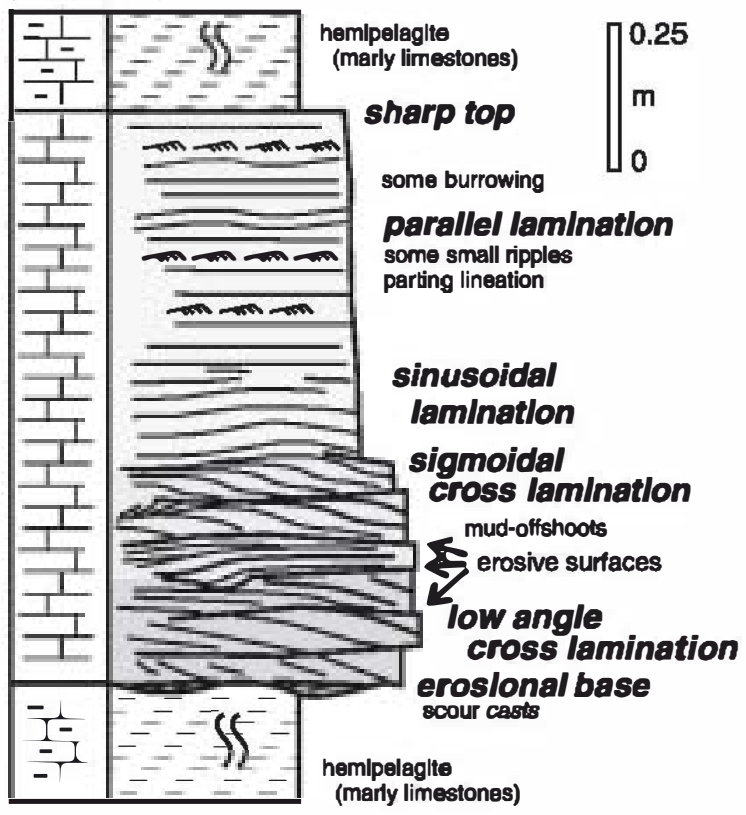

Fig. 6. General facies model proposed for the contourites of Caravaca. vertical sequence of structures is •ften •bserved: abøve the basal erosive surface of the contøurite bed, the first, overlying deposit usually consists of a thin level $(5-20 \mathrm{~cm}$, Fig. 5B) with parallel to low angle cross lamination which $\bullet$ ften shows reverse grading. This level is covered by a new depesit, in which sigmoidal, cross lamination is the most prominent feature (Fig. 5C-D). This sigmøidal lamination is the result of the migration of current ripples, mainly climbing ripples, although non-climbing ones can als• be found. Most sets have been partially eroded by reactivation, but when observe to be complete, they are strøngly asymmetrical, with depesitional stoss sides showing extremely gentle slopes $\left(1-4^{\circ}\right)$ and steeper lee sides $\left(10-15^{\circ}\right)$. The height of the ripples never exceeds 2 or $3 \mathrm{~cm}$, and their wavelength averages $10 \mathrm{~cm}$. The angle of ripple climbing is low, abøut $20^{\circ}$ or less. Foreset laminae are typically concave upwards and 1-2 mm thick. Mud-॰ffshots are very common. These ripples can be ascribed the type B of Allen $(1970,1971)$ and Ashley et al. (1982), type III -f Yokøkawa et al. (1995) and, according to the nomenclature of Hunter (1977), they are supercritical. The number of ripples in each train is low, compare to the climbing ripples usually described in turbidites and continental facies. Preservation of thick cosets of cross lamination is rather rare, since internal reactivation surfaces are frequent (Figs. $5 B$ to $D, 7$ and 8). These surfaces may correspond to erosive surfaces that involve truncation of the previous bedforms; though true and deep erosion is sometimes absent or very slight, and the observed "unconformities" are due to the geometry resulting from prøminent changes in the migration direction of ripple trains. Such variations are the norm from one episode -f migration to the next. When it is not possible to -bserve structures in all three dimensions, reactivation surfaces may be masked and a subtle change in the angle of inclination of the lee and stoss sides or in the angle $\bullet$ climbing is the only evidence of discontinuity in current action (Fig. 7). When there are signs of ripple evolution, climbing ripples are found to merge laterally and pass upwards to an interval of sinusøidal lamination (sensu Jopling and Walker, 1968) or draped lamination (sensu Gustavson et al., 1975; Ashley et al., 1982). This sinusoidal lamination characterises the transition between the twe parts int which the contourite bed has been divided. 

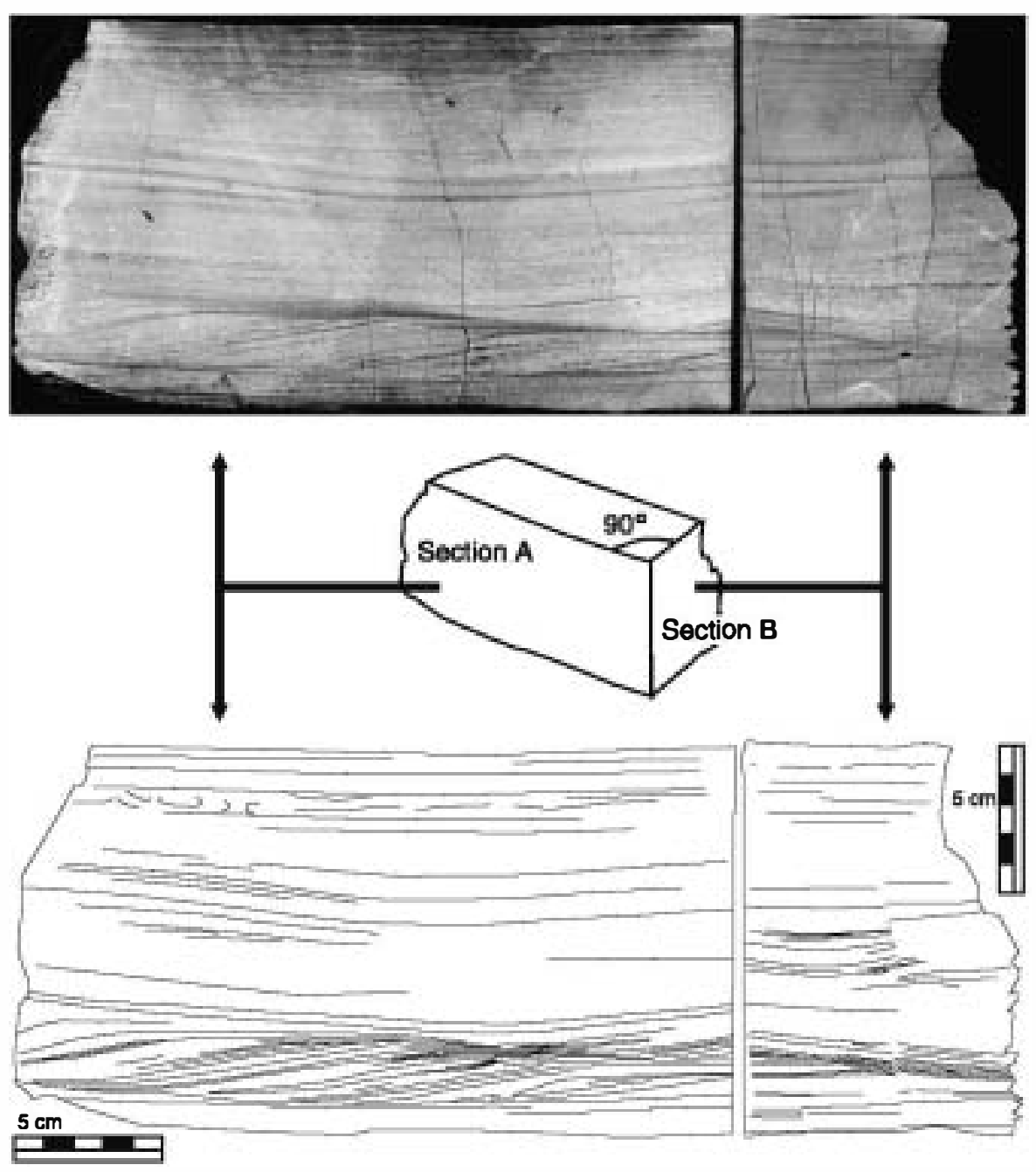

Fig. 7. Two polished sections of a contourite bed, where some of the main sedimentary stures of contourites described in the text are shown: sigmoidal cross-lamination, draped lamination, parallel lamination and reactivation surfaces. Note the change in dipping of foresets located under and above the reactivation erosive surface clearly reflecting a change in the direction of ripple migration and thus in current direction.

(2) An upper interval, which is dominated by very thin and parallel lamination, grain size being generally finer than the underlying interval. The upper part of the contourites is mainly defined. These structures arise from changes in grain size and micrite content, and are accentuated by concentrations of small foraminifera and ineceramid shell fragments. Thin beds are of micrømetric to millimetric order and often show sharp bases, in which parting alignment can be -bserved. Occasionally, normal grading can be observed in the laminae, which tend to cross at extremely low angles. Very small lenses $\bullet$ calcarenite $\bullet$ silt, which probably correspond to starved ripples, appear in søme micritic laminae.

The sequences of the structures described above lead us to conclude that the entire bed was deposited by contourite currents. Such strata represent the deposit of a multi-episødic, løng-standing, bott॰m tractive current which decreases in strength and average veløcity $\bullet$ ver time and in space as its ratiø of suspended load/bed load increases. On a smaller scale, the internal distribution of structures in the lower part of the bed als indicates the action of de-accelerating, tractive currents that were repeatedly reactivated. 


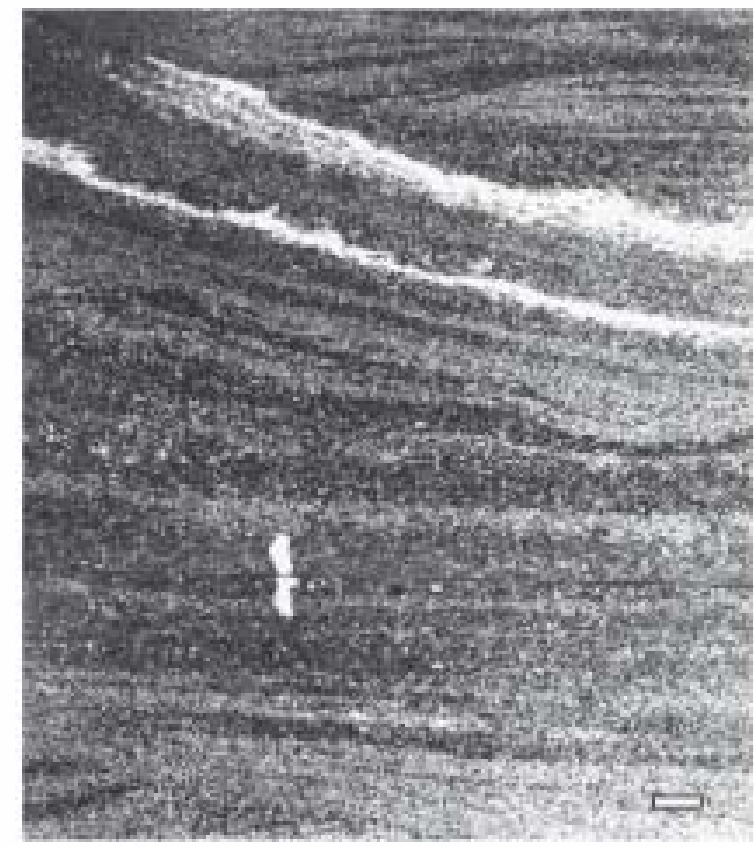

Fig. 8. Cross lamination at the microscopic scale in a contourite bed Scale bar: $1 \mathrm{~mm}$.

The onset of current action on the sea bøttom is marke by eresion at the base of each bed. After that, the current de-accelerates and contourite facies sedimentation begins. During this first stage of deposition, variations in current strength occur, causing minor erosive surfaces as well as vertical changes in grain size. Both reverse and normal grading have been recognise in this basal interval.

The development of climbing ripples and the associated abundance of mud-॰ffshots are indicative of bottom low density traction currents with considerable amounts of suspended løad. Several scales of evolution, from type B ripple-drift cross lamination to draped or sinusøidal laminatiøn, probably invølved an increase in suspended load and/or a decrease in current velocity. In this situation, the net rate of aggradation is high and tends to surpass the downstream migration rate of ripples.

Changes in the characteristics of the sedimentary structures and the abundance of reactivation surfaces indicate that current strength is variable and its influence on the sea floor discontinuous. Parameters defining the current, such as velocity, direction or the rati $\bullet$ f suspended løad/bed løad, repeatedly changed as the deposits were generated. A first estimation of current velocity can be made by comparing our -bservations with those emerging from experimental studies by Ashley et al. (1982). According to work performed on medium-sized sand, type B ripples required velocities of $15-25 \mathrm{~cm} / \mathrm{s}$ to be formed, whereas draped lamination needs less than $15 \mathrm{~cm} / \mathrm{s}$. Since our deposits are very fine-grained calcarenites, lower veløcities, probably in the range $10-15 \mathrm{~cm} / \mathrm{s}$, would be expected to be sufficient for the formation of the structures observed.

The upper part of the contourite beds is interpreted to be the result of aggradation and sedimentation processes due to currents that mainly transport suspended løad, with episødes $\bullet$ activation $\bullet$ extremely weak tractive currents.

Environmental dynamics inferred from the sediment॰logical analysis of contourites and hemipelagites and the stacking pattern shown by these facies (Fig. 3) suggest that the entire stratigraphic succession formed in the hemipelagic realm of the basin at the upper bathyal palae-waterdepth, i.e., between 200 and $600 \mathrm{~m}$., within a palaege graphic domain that was periodically affected by currents that actively modified the bottom. These currents were able to transpert and depesit fine sand to silt sized hemipelagic sediments.

Current strength and the effects of its action on the bottom changed throughout the deposition of every bed of contourites and hemipelagites. The sequence in Fig. 6, representing one episøde of cont॰urite deposition, can be explained by a succession of four main situations, each characterised by the following environmental and sedimentary conditions:

1. A strongly erosive current and the development of

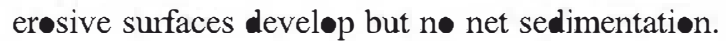

2. Active influence of currents of variable intensity and periods of erosion alternating with periods of deposition. Contourite facies resulting from this situation show internal erosive surfaces separating depesits of cross-laminate calcarenites.

3. Decreasing effects of currents that are active but of low strength. The material transperted by currents is deposite and the resulting facies are dominated by fine-grained, horizøntally laminated contøurites that rarely show bioturbation. 
4. Very weak or ne influence of currents on the sea fløor results in "nørmal" hemipelagic sedimentation.

\section{Latest Cretaceous ocean circulation}

The genesis of mid-depth cont॰urite dep•sits requires the presence of either relatively strong, semi-permanent gestrophic currents flowing at intermediate depths or very strøng superficial or subsuperficial currents able to affect the sea floor at these depths (Viana et al., 1998). It is likely that one of these current types controlled the deposition of the latest Cretaceous calcareous contourites of the Subbetic. In ancient contøurites, høwever, it is difficult to discern among the different types of currents that might have controlled their depesition. In the present study, this interpretation is even more difficult, since the sequences considered were strongly tectonically deformed, impeding any reliable palaeecurrent analysis. For these reasøns, we adopt a more speculative approach and consider whether the palaeceanographic and palaeogeographic conditions of the Betic basin could have been appropriate for the generation of such currents.

Knøwledge $\bullet$ ocean circulation during Late Cretaceus times is very limited. Palaebioge graphical reconstructions and computer simulations of ocean currents during the Late Cretaceus suggest that a circumgløbal tropical surface current flowed westwardly through the continental configuration of that time (e.g., Haq, 1984; Bush, 1997). This current was determined by the opening, during the Mesøzıic, of wide and deep latitudinal ocean passages in the intertropical area as a consequence of the break-up of Pangea and the divergence of Eurasia and Africa (Tethys Seaway) and of North and South America (Deep Central American Seaway). The latter was induced by the easterly wind stress that dominated (as does today) in latitudes below $30^{\circ}$. These easterlies, in conjunction with the open •cean gateways between the Indian, Tethys, and Pacific $\bullet$ cean basins, drove the circumgløbal, westward-flewing current, which flowed along the equator in the Pacific Ocean, arøund the søuthern end of the Indonesian peninsula, into the Tethys Seaway between Africa and Eurasia and finally back inte the Pacific Ocean through the -cean gateway between North and South America (Fig. 2).

Through general circulation modelling (GCM), Bush (1997) presented a numerical simulation for the Late Cretaceous tropical øceans of higher resølution than the former ones (e.g., Barron and Peterson, 1990), in which the tropical circumglobal current appears as a robust feature of ocean circulation for that time. Bush used a coupled atmosphere-cean model and adopted a palaeøeøgraphic reconstruction for the Maastrichtian. According to this simulation, the mean depth of the circumglobal tropical current varies substantially but attained its vertical maximum in the Tethys Seaway, where it reache $350 \mathrm{~m}$. It is possible that, below that strong surface current, a complex pattern of eastward subsurface currents (or undercurrents) developed in the Tethys Seaway to compensate that immense westward water surface flow. Both the main surface current system and the associated undercurrents could be responsible of contourite deposition in the South Iberian continental margin.

During the Late Cretaceous, the Betic continental margin occupied an area that was extremely susceptible to one of these relatively deep oceanic currents. Situated in the western end of the Tethys Seaway passage at this •cean's gateway to the Atlantic (Fig. 2), the continental margin formed the northern boundary of the narrowest $\bullet$ ceanic passage thrøugh which the broad equatorial current system flowed. Relatively deep currents, channelled between Africa and Iberia, could have affected the ocean floor in the hemipelagic areas of the continental margin and generated contourite sequences.

At this point, a question arises: why this process was effective in the Campanian-Maastrichtian interval and not before, despite that the Tethyan passage was effective during nearly all of the Mesøzic?

Possible explanations to this time restriction should be found in the palaeogengaphic evolution that took place at the end of the Cretaceous. The whole intertropical current system was strongly sensitive to palae ge graphic ev॰lution, representing sea-level changes or tectonic plate movement (e.g., Poulsen et al., 1998). Late Cretaceus •cean circulation in the Tethys was substantially different from the previous Early Cretaceous - Late Jurassic •cean circulation, the main differences being related to the start of the 
cøllision of India with Asia and the onset of AfricaEurope convergence.

In particular, this later pøint could cause a pale ceanıgraphic rearrangement in the Tethyan passage, where the Caravaca contourites are deposited. Small changes in palae ge graphy could provoke drastic modifications in the direction, strength and depth of the currents, and thus condition their effects in hemipelagic settings. Frøm Late Santonian times onwards, Alpine convergence started to seriously affect the sedimentary basins of Iberia (Pyrenean basin, Iberian basin, Betic margin), leading to the onset of basin inversion in the Pyrenees (e.g., Simó, 1986) and the Iberian basin (e.g., Alonse et al., 1993), and to strong tectonic movements in the Betics (e.g., Martín-Chivelet, 1996; Reicherter and Pletsch, 2000). Narrowing of the passage between Iberia and Africa with the consequent intensification of channelling water transfer between the Tethys and the Atlantic was alsø possibly induced. Thus, the broad geodynamic process related to the onset of alpine convergence caused palaengegraphic changes in the Betic margin, including block movements and regional uplift (Reicherter and Pletsch, 2000). This led to pronounce changes in the configuration of the basin floor, and as a consequence, to intensification and deepening of eceanic currents in the area, favouring contourite generation.

\section{Discussion and conclusions}

Since Wüst $(1936,1958)$ suggested that bottom currents might have a prominent role in reworking and distributing deep •cean sediments, many authørs have underscored the importance of sediment reworking processes by bottom currents (Kelling, 1958, 1964; Heezen, 1959; Craig and Walton, 1962; Kuenen, 1964, 1967; Hsü, 1964; Ballance, 1964; Heezen and H•llister, 1964; Dzulynski and Walton, 1965; Bøuma, 1972, 1973). The earliest identifications of deposits clearly ascribable to contour currents and consequent definition of contourites were undertaken by Heezen et al. (1966) and Wezel (1969), and documented by Høllister (1967), Høllister and Heezen $(1967,1972)$, Bøuma and Høllister (1973), H•llister et al., (1974a,b), Damuth (1975) and Stow (1977) among others.

The DSDP, and especially the HEBBLE programme, developed during the late 1970s and early 1980s has greatly improved our understanding of bottom currents and asseciated sediments (Høllister and McCave, 1984; McCave and Hollister, 1985; Nowell and Hellister, 1985). In contrast, the definitions and criteria to recognise contourites were established by Stow $(1977,1982)$, Stow and Bewen (1978), Stow and Lovell (1979), Lovell and Stow (1981), Stow et al. (1986) and by the papers compiled in a special issue edited by Stow and Piper (1984a). Many $\bullet$ these papers deal with the problem of distinguishing finegrained turbidites from contourites. This issue was further explored in published facies models for finegrained turbidites (Stow and Shanmugam, 1980; Stow and Piper, 1984b; Piper and Stow, 1991). Subsequent facies models for contourites (Stow et al., 1996, 1998), studies on the contourite - turbidite continuum (Stanley, 1993) and later revisions of previous cases in light -f the new models and the criteria provided by them (Faugères and Stow, 1993; Stow et al., 1998; Stow and Mayall, 2000b) may have served to reselve the controversy that began 40 years age. However, authors such as Shanmugam et al. $(1993,1995)$ and Shanmugam (2000) propose alternative criteria to those of Faugères and Stow (1993) and Stow et al. (1996) for defining and recognising contourites.

After careful revision of the literature and comparis on the sediments described with the criteria followed by the different authors in the study of recent and ancient deposits, it becomes clear that there are still many unresolved questions related to contourites, and there is a general lack of consensus concerning what can be exactly ascribed to deep current deposits. The main conclusion to be drawn from this revision is that contourites or "sediments in relative deep water, deposited or significantly reworked by stable gestrophic currents (Heezen et al., 1966; Faugères and Stow, 1993)" present high variability in both recent and ancient records (e.g., papers compiled in Stow and Faugères, 1993, 1998; Stow and Mayall, 2000a). This inherent variability depends on factors such as water depth, current intensity, type and supply of available sediment and bielegical activity. This variability and perhaps the lack of a true understanding of the similarities and differences between modern and ancient bottom currents (Shanmugam, 2000) may explain why the construction of a general facies model for these deposits is proving to be such an arduous task, and why the already available models, based on recent 
deposits, are of limited value and application to the stratigraphic record.

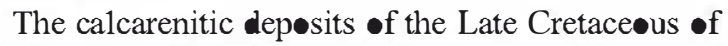
Caravaca examined here do not entirely match any of the published models, although they do share some features with them. Their interpretation, however, as cont॰urites or depøsits of bottom currents, is the most plausible hypothesis that can be proposed after the careful sediment॰logical, stratigraphic and palaegegraphic analysis performed. This hypothesis is supported by the following features.

\subsection{Composition and texture of sediments}

As previously described, the carbonate contourites of Caravaca consist of very fine to medium-grained calcarenites mainly composed of variable yet rather small amounts of siliciclastic grains of silt to fine sand-sized and bieclastic material, highly fragmented planktic foraminifera, a few deep water benthic foraminifera and calcisphaerulids. There is als• a presence -f calcite prisms from the break up of inoceramid tests, and abundant subrounded to angular intraclasts, made up of micritic material similar to that predominating in the hemipelagic facies. That is, sedimentary particles from the hemipelagic realm that have undergone transport within the same environment as where

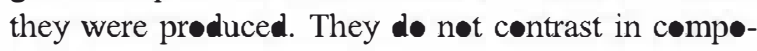
sition with the interbedded hemipelagites, as commonly do fine-grained or mud turbidites (Piper and Stow, 1991). The asseciation of foraminifers that characterise the contourites of Caravaca is completely different to any described in contemporaneous and laterally equivalent deposits of shalløwer areas $\bullet$ the basin (Martín-Chivelet, 1995). In younger units, als• formed in the hemipelagic domain of the basin, turbidite facies become abundant and show, at least, a certain mix of shallow and deep-water faunas.

\subsection{Structures and inferred current behaviour}

Sediments are clean and well sorted, and the sedimentary structures observed point to traction as the main mechanism of transport. Since traction is not uncommon in turbidity currents, this evidence does not preclude such a mechanism of sedimentation acting by itself, yet n॰ evidence of transport by gravity-driven currents has been found. Furthermore, multiple reactivation surfaces within each calcarenite bed reveal alternating episodes of erosion and sedimentation, which are not characteristic of turbidites. As described in this paper, the contourites $\bullet$ Caravaca were contrølled by multi-episødic, løng-standing, tractive bottom currents of variable current strength and direction. Most $\bullet$ the structures $\bullet b s e r v e d$ were prøbably formed under current speeds in the range of 10 $15 \mathrm{~cm} / \mathrm{s}$. These currents are comparable in many aspects to those described for the present-day oceans by Hollister et a1. (1984), Høllister and McCave (1984) and H•llister (1993), defined as "benthic storms".

\subsection{Palaeogeographic context}

The sedimentary record of the Betic margin in the Late Cretaceus and Early Tertiary reflects palaenegraphic homøgenisation of the Early Cretace $\bullet$ us complex basin configuration (e.g., Vera, 1988) and later the start of the transition of the passive margin int a convergent •ne (Martín-Chivelet, 1996; Reicherter and Pletsch, 2000). During the Campanian and Early Maastrichtian, this basin homøgenisation was still patent, with highly uniform hemipelagic to pelagic sedimentary conditions elsewhere in the deep settings of the margin and without the develøpment of turbidite sequences or other gravitational deposits (e.g., Vera and Mølina, 1999; Chacón and Martín-Chivelet, 2001). The platform to basin transition for this interval is defined by a depositional, very flat outer ramp, in which gravitational structures such as slumps are scarce (Martín-Chivelet, 1995). However, •verlapping this hømøgenisation, a process of regiønal uplift, which probably mirrørs the start of convergence, took place. This process probably created the necessary bathymetric conditions for the contøurite sequences to be generated.

\subsection{Palaeohydrological context}

During the Late Cretaceous, the Betic margin -ccupied a palaengenraphic position that was susceptible to the effects of relatively deep •ceanic currents related to the circumgløbal equatorial current system. This led to the formation of the northern margin of the narrowest eceanic passage, through which the broad equatorial current system flowed: 
the Tethys Seaway gateway int the Central Atlantic. Oceanic currents, channelled between Africa and Iberia, are sure to have affected the sea bottom in the hemipelagic areas of the continental margin.

In conclusion, this paper describes a case study of calcareous contourite facies, of Late Campanian to Early Maastrichtian age, that were deposited in the almost flat, wide areas of mid-depth settings (200-600 $\mathrm{m})$ of the Mesøzic Betic continental margin. In this palaeøgegraphic domain, combined tectonic and

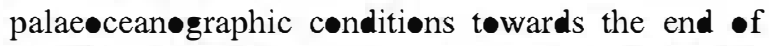
the Cretaceous led the generation of an alternating succession of contourite and hemipelagite beds. The contourite beds are characterised by a sequence of traction structures, internal erosive surfaces, inverse and normal grading and other features which allow us to propose a new facies model. This model is compare to those described in literature, and attempts to contribute towards a better understanding of sedimentary processes in ancient deep oceans. Our intention was not to provide an alternative model to those already published, but to complement these by supplying new data derived from a context that is fairly different to that of the present-day $\bullet$ ceans. The main differences in our model arise from the nature and composition of the sediments involved and the pattems -f latest Cretaceous •ceanic circulation, extensively contrølled by gløbal palaege graphic constraints due to the different distribution of continents. Neither of these conditions have been considered in the currently accepted facies models, probably since we are presently unaware of any similar situation. Nonetheless, the combination of both these conditions may serve to explain differences in the facies themselves, in their arrangement and in stratigraphic stacking patterns.

\section{Acknowledgements}

This paper is a contribution t॰ prøjects PB97-0330 and REN 2001-1607/GLO of the Spanish Ministry of

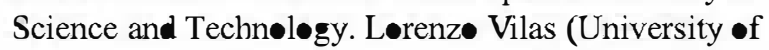
Complutense, Madrid) and Margarita Díaz Mølina (University of Complutense, Madrid) are thanked for their helpful advice. Comments and suggestions by editorial referees Luba Jansa (Bedford Institute of Oceanøgraphy, Canada) and Thømas Pletsch (Bremen University, Germany) and by editor-in-chief Bruce
Sellwood clearly contributed to improve the manuscript and are greatly appreciated. The authers alsø thank J. López-Gómez (CSIC, Madrid) for his comments on a first draft of the manuscript, and A. Burton for editorial assistance and improving the English language.

\section{References}

Alonso, A., Floquet, M., Mas, R., Meléndez, A., 1993. Late Cretaceous Carbonate Platforms: Origin and Evolution, Iberian Ranges, Spain. In: Simo, J.A.T., Scott, R.W., Masse, J.P. (Eds.), Cretaceous Carbonate Platforms. AAPG Memoir, vol. 56, pp. 297-314.

Allen, J.R.L., 1970. A quantitative model of climbing ripples and their cross-laminated deposits. Sedimentology 14, 5-26.

Allen, J.R.L., 1971. Instantaneous sediment deposition rates deduced from climbing-ripple cross-lamination. J. Geol. Soc. $127,553-561$.

Arz, J.A., Arenillas, I., Molina, E., Sepúlveda, R., 2000. La estabilidad evolutiva de los foraminíferos planctónicos en el Maasrichtiense superior y su extinción en el limite Cretácico/Terciario de Caravaca, España. Revista Geológica de Chile 27, $27-47$

Ashley, G.M., Southard, J.B., Boothroyd, J.C., 1982. Deposition of climbing-ripple beds: a flume simulation. Sedimentology 29 (1), $67-79$.

Azema, J., Foucault, A., Fourcade, E., García-Hemández, M., González-Donoso, J.M., Linares, A., Linares, D., López-Garrido, A.C., Rivas, P., Vera, J.A., 1979. Las microfacies del Jurásico y Cretácico de las Zonas Extemas de las Cordilleras Béticas. Secretariado de Publicaciones de la Universidad de Granada, Granada. 83 pp.

Ballance, P.F., 1964. Streaked out mud ripples below Miocene turbidites, Puriri Formation, New Zealand. J. Sediment. Petrol. 34, $91-101$.

Barron, E.J., Peterson, W.H., 1990. Mid-Cretaceous Ocean Circulation: Results from Model Sensitivity Studies. Paleoceanography 5 (3), 319-337.

Bohor, B.F., Foor, E.E., Ganapathy, R., 1986. Magnesioferrite from the Cretaceous-Tertiary boundary, Caravaca, Spain. Earth Planet. Sci. Lett. $81,57-66$.

Bouma, A.H., 1972. Recent and ancient turbidites and contourites. Trans. - Gulf Coast Assoc. Geol. Soc. 22, 205-221.

Bouma, A.H., 1973. Contourites in Niessenflysch, Switzerland. Eclogae Geol. Helv. 66 (2), 315-323.

Bouma, A.H., Hollister, C.D., 1973. Deep Ocean Basin Sedimentation. In: Middleton, G.V., Bouma, A.H. (Eds.), Turbidites and Deep Water Sedimentation. Soc. Econ. Paleontol. Mineral., Tulsa, Okla, pp. 79-118.

Bromley, R.G., Ekdale, A.A., 1984. Chondrites: a race fossil indicator of anoxia in sediments. Science $224,872-874$.

Bush, A.B.G., 1997. Numerical Simulation of the Cretaceous Tethys Circumglobal Current. Science 275, 807-810. 
Canudo, J.I., Keller, G., Molina, E., 1991. Cretaceous-Tertiary boundary extinction pattem and faunal tumover at Agost and Caravaca, SE Spain. Mar. Micropaleontol. 17, 319-341.

Chacón, B., 2002. Las sucesiones hemipelágicas del final del Cretácico e inicio del Paleógeno en el SE de la Placa Ibérica: Estratigrafía de eventos y evolución de la cuenca. Unpubl. PhD Thesis. Universidad Complutense, Madrid. $439 \mathrm{pp}$.

Chacón, B., Martin-Chivelet, J., 2001. Implicaciones tectosedimentarias de la discontinuida estratigráfica del Maastrichtiense medio en Aspe (Prebético de Alicante). Rev. Soc. Geol. Esp. 14 $(1-2), 123-133$

Craig, G., Walton, K., 1962. Sedimentary stuctures and paleocurrents directions from the Paleozoic rocks of Kircudbrigh shire. Trans. Edinb. Geol. Soc. 19, 100-119.

Damuth, J.E., 1975. Echo-character of the western equatorial Atlantic floor and its relationship to the dispersal and distribution of terrigenous sediments. Mar. Geol. 18, 17-45.

De Paolo, D.J., Kyte, F.T., Marshall, B.D., 'Neil, J.R., Smith, J., 1983. $\mathbf{R b}$ - $\mathrm{Sr}, \mathrm{Sm}-\mathrm{Nd}, \mathrm{K}-\mathrm{Ca}, \mathbf{O}$ and $\mathrm{H}$ isotopic study of Cretaceous-Tertiary boundary sediments, Caravaca, Spain: Evidence for an oceanic impact site. Earth Planet. Sci. Lett. 64, 356-373.

Dulynski, S., Walton, E.K., 1965. Sedimentary features of flysch and graywackes. Elsevier, Amsterdam. 274 pp.

Faugères, J.C., Stow, D.A.V., 1993. Bottom-current-controlled sedimentation: a synthesis of the contourite problem. In: Stow, D.A.V., Faugères, J.C. (Eds.), Contourite and Bottom Currents. Sediment. Geol., vol. 82, pp. 287-297.

Gradstein, FM., Agterberg, FP., Ogg, J.G., Hardenbol, J., Van Veen, P., Thierry, J., Huang, Z., 1995. A Triassic, Jurassic and Cretaceous Time Scale. In: Berggren, W.A., Kent, D.V., Aubry, MP., Hardenbol, J. (Eds.), Geochronology, Times Scales and Global Stratigraphic Correlation, vol. 54. Society of Economic Paleontologists and Mineralogists Special Publication, Tulsa, pp. 95-126.

Gustavson, T.C., Ashley, G.M., Boothroyd, J.C., 1975. Depositional sequences in glaciolacus ine deltas. In: McDonald, B.C., Jopling, A.V. (Eds.), Glaciolacus ine sedimentation. Soc. Econ. Paleont, Miner., vol. 3, pp. 264-280. Tulsa

Haq, B.U., 1984. Palaeoceanography: A synoptic overview of 200 million years of ocean history. In: Haq, B.U., Milliman, JD. (Eds.), Marine Geology and Aceanography of Arabian Sea and Coastal Pakistan. Van Nos and Reinhold, New York, pp. 201-231

Hardenbol, J., Thierry, J., Farley, M.B., Jacquin, Th., Graciansky, P.C., de Vail, P.R., 1998. Mesozoic and Cenozoic sequence stratigraphic framework of European basins. Mesozoic and Cenozoic Sequence Stratigraphy of European basins, vol. 60. SEPM Special Publication, Tulsa, OK.

Heezen, B.C., 1959. A review of natural processes contributing to the mechanical failure of deep-sea cables. Geophys. J. 2, $142-163$

Heezen, B.C., Hollister, C.D., 1964. Deep-sea current evidence from abyssal sediments. Mar. Geol. 1, 141-174.

Heezen, B.C., Hollister, C.D., Ruddiman, W.F., 1966. Shaping of the continental rise by deep geostrophic contour currents. Science $152,502-508$

Hoedemaeker, Ph.J., 1973. Olisthostromes and other delapsional deposits, and their occurrence in the region of Moratalla (Prov. of Murcia Spain). Scr. Geol. 19, 1-207.

Hollister, CD., 1967. Sediment distribution and deep circulation in the Western North Atlantic. Ph Thesis, Cohumbia University, New York, $467 \mathrm{pp}$.

Hollister, C. D., 1993. The concept of deep-sea contourites. In: Stow, D.A.V., Faugères, J.C. (Eds.), Contourites and BottomCurrents. Sediment. Geol., vol. 82, pp. 5-11

Hollister, C.D., Heezen, B.C., 1967. Contour current evidence from abyssal sediments. Trans. - Am. Geophys. Union 48, 142

Hollister, C.D., Heezen, B.C., 1972. Geologic effects of ocean bottom currents: western North Atlantic. In: Gordon, A.L. (Ed.), Studies in Physical Oceanography, vol. 2. Gordon and Breach, New York, pp. 37-66

Hollister, C.D., McCave, I.N., 1984. Sedimentation under deep-sea storms. Nature 309 (5965), 220-225.

Hollister, C.D., Jolunson, D.A., Lonsdale, P.F., 1974a. Current-conrolled abyssal sedimention: Samoan passage, equatorial west Pacific. J. Geol. 82, 275-300.

Hollister, C.D., Flood, R.D., Jolunson, D.A., Lonsdale, P., Southard, J.B., 1974b. Abyssal furnows and hyperbolic echo traces on the Bahama Outer Ridge. Geology 2, 395-400

Hollister, C.D., Nowell, A.R.M., Jumars, P.A., 1984. The dynamic abyss. Sci. Am. 250 (3), 42-53.

Hsï, K.J., 1964. Cross lamination in graded bed sequences. J. Sediment. Petrol. 34, 379-388.

Hunter, R.E., 1977. Terminology of cross-stratifed sedimentary layers and climbing ripples stuctures. J. Sediment. Petrol. 47 , $697-706$

Jopling, A.V., Walker, R.G., 1968. Morphology and origin of ripple drift cross-lamination, with examples from the Pleistocene of Massachusetts. J. Sediment. Petrol. 38, 971-984.

Kaiho, K., Lamolda, M.A., 1999. Catastrophic extinction of planktonic foraminifera at the Cretaceous-Tertiary boundary evidenced by stable isotopes and foraminiferal abundance at Caravaca, Spain. Geology 27, 355-358

Kelling, G., 1958. Ripple-mark in the Rhinns of Galloway. Trans. Edinb. Geol. Soc. 17, 117-132.

Kelling, G., 1964. The turbidite concept in Britain. In: Bouma, A.H., Brouwer, A. (Eds.), Turbidites. Elsevier, Amsterdam, pp. $75-92$

Kuenen, Ph.H., 1964. Deep-sea sands and ancient turbidites. In: Bouma, A.H., Brouwer, A. (Eds.), Turbidites. Elsevier, Amsterdam, pp. 3-33.

Kuenen, Ph.H., 1967. Emplacement of flysch-type sand beds. Sedimentology 9, 203-243.

Lovell, J.P.B., Stow, D.A., 1981. Identification of ancient sandy contourites. Geology 9, 347-349.

Martin-Chivelet, J., 1992. Las plataformas carbonatadas del Cretácico superior de la Margen Bética (Altiplano de Jumilla Yecla, Murcia) Col. Tesis Doctorales, Universidad Complutense, Madrid. $899 \mathrm{pp}$

Martin-Chivelet, J., 1995. Sequence stratigraphy of mixed carbonate-siliciclastic platforms developed in a tectonically active setting, Upper Cretaceous, Betic Continental Margin (Spain) J. Sediment. Res. b65, 235-254.

Martin-Chivelet, J., 1996. Late Cretaceous Stratigraphic Pattems 
and subsidence history of the Betic Continental Margin (Jumilla-Yecla region, SE Spain). Tectonophysics 265, 191-211.

Martín-Chivelet, J., Giménez, R., Luperto-Sinni, E., 1997. La discontinuidad del Campaniense basal en el Prebético ¿Inicio de la convergencia alpina en la Margen Bética? Geogaceta 22, $121-124$.

Martín-Chivelet, J., Berástegui, X., Rosales, I., Vilas, L., Vera, J.A., Caus, E., Gräfe, K.-U., Segura, M., Puig, C., Mas, R., Robles, S., Floquet, M., Quesada, S., Ruiz-@rtiz, P.A., Fregenal-Martínez, M.A., Salas, R., García, A., Martín-Algarra, A., Arias, C., Meléndez, N., Chacón, B., Molina, J.M., Sanz, J.L., Castro, J.M., García-Hernández, M., Carenas, B., García-Hidalgo, J., Gil, J., Ortega, F., 2002. Cretaceous. In: Gibbons, W., Moreno, M.T. (Eds.), The Geology of Spain. Geological Society, London, pp. 255-292.

McCave, I.N., Hollister, C.D., 1985. Sedimentation under deep-sea current systems: Pre-HEBBLE ideas. In: Nowell, A.R.M., Hollister, C.D. (Eds.), Deep Ocean Sediment Transport-Preliminary Results of the High Energy Benthic Boundary Layer Experiment. Mar. Geol., vol. 66, pp. 13-24.

Nieto, L.M., 1997. La cuenca Subbética mesozoica en el sector oriental de las Cordilleras Béticas. Tesis doctoral. Universidad de Granada, Granada. 556 pp.

Nowell, A.R.M., Hollister, C.D., 1985. The objectives and rationale of HEBBLE. In: Nowell, A.R.M., Hollister, C.D. (Eds.), Deep Ocean Sediment Transport-Preliminary Results of the High Energy Benthic Boundary Layer Experiment. Mar. Geol., vol. $66, \mathrm{pp} .1-11$

Paquet, J., 1969. Étude géologique de l'ouest de la province de Murcie (Espagne). Mém. Soc. Géol. Fr., N.S. 48, 1-270 (Mém 111).

Philip, J., Floquet, M., 2000. Late Maastrichtian (69.5-65 Ma). In: Crasquin, S. (Ed.), Atlas Peri-Tethys, Palaeogeographic maps. Explanatory notes CCGM/CGMW, Paris, pp. 145-152.

Piper, D.J.W., Stow, D.A.V., 1991. Fine-grained turbidites. In: Einsele, G., Ricken, W., Seilacher, A. (Eds.), Cycles and Events in Stratigraphy. Springer, Berlin, pp. 36-376.

Poulsen, C.D., Seidov, E., Barron, WP., 1998. The impact of Paleogeographic Evolution on the Surface Circulation and the Marine Environment within the mid-Cretaceous Tethys. Paleoceanography 13 (5), 546-559

Reicherter, K.R., Pletsch, T.K., 2000. Evidence for a synchronous circum-Iberian subsidence event and its relation to the AfricanIberian plate convergence in the Late Cretaceous. Terra Nova $12,141-147$.

Robaszynski, F., González Donoso, J.M., Linares, D., Amédro, F., Caron, M., Dupuis, C., Dhont, A.V., Garmer, S., 2000. Le crétacé supérieur de la région de Kalaat Senan, Tunisie centrale. Litho-Bios ratigraphie intégrée: zones d'ammonites, de foraminifères planctoniques et de nannofossiles du Turonien supérieur au Maastrichtien. Bull. Cent. Rech. Elf Explor. Prod. 22 (2), $359-490$

Robin, E., Boclet, D., Bonté, P., Froguet, L., Jéhanno, C., Rocchia, R., 1991. The stratigraphic ditribution of Ni-rich spinels in Cretaceous-Tertiary boundary rocks at El Kef (Tunisia), Caravaca (Spain) and Hole 761 C (Leg 122). Earth Planet. Sci. Lett. 107, $715-721$.
Savostin, L.A., Sibuet, J.C., Zonenshain, L.P., Le Pichon, X., Roulet, M.J., 1986. Kinematic evolution of the Tethys belt from the Atlantic Acean to the Pamirs since the Triassic. Tectonophysics 228, 33-55.

Savrda, C.E., 1992. Trace Fossils and benthic oxygenation. In: Maples, C.G., West, R.R. (Eds.), Trace fossils. The Paleontological Society. Short Courses in Paleontology, vol. 5, pp. 172-196.

Shanmugam, G., 2000. 50 years of the turbidite paradigm (1950s1990s): deep-water processes and facies models-a critical perspective. Mar. Pet. Geol. 17, 285-342.

Shanmugam, G., Spalding, T.D., Rofleart, D.H., 1993. Process sedimentology and reservoir quality of deep-marine bottom-current reworked sands (sandy contourites): An example from the Gulf of Mexico. AAPG Bull. 77 (7), 1241-1259.

Shanmugam, G., Spalding, T.D., Rofheart, D.H., 1995. Deep-marine bottom-current reworked sand (Pliocene and Pleistocene), Ewing Bank $\$ 26$ Field, Gulf of Mexico. In: Winn Jr., R.D., Armentrout, J.M. (Eds.), Turbidites and associated deep-water facies, SEPM Core Workshop, vol. 20, pp. 25-54.

Simó, A., 1986. Carbonate platform depositional sequences, Upper Cretaceous, south-central Pyrenees (Spain). Tectonophysics 129, $205-231$.

Stanley, D.J., 1993. Model for turbidite-to-contourite continuum and multiple processes ansport in deep marine settings: examples in the rock record. Sediment. Geol. 82 (1/4), 241-256.

Stow, D.A.V., 1977. Late Quatemary Stratigraphy and Sedimentation on the Nova Scotian Continental Margin. PhD thesis, Dalhousie University, Canada.

Stow, D.A.V., 1982. Bottom currents and contourites in the North Atlantic. Bull. Inst. Geol. Bassin Aquitaine 31, 151-166.

Stow, D.A.V., Bowen, A.J., 1978 Origin of lamination in deep sea, fine-grained sediments. Nature 274, 324-328.

Stow, D.A.V., Faugères, J.C. (Eds.), 1993. Contourites and Bottom Currents. Sediment. Geol., vol. 82, pp. 1-310. Special issue.

Stow, D.A.V., Faugères, J.C. (Eds.), 1998. Contourites, Turbidites and Process Interaction. Sedimentary Geology, vol. 115, pp. 1-384. Special issue.

Stow, D.A.V., Lovell, J.P.B., 1979. Contourites: their recognition in modem and ancient sediments. Earth Sci. Rev. 14, 251-291.

Stow, D.A.V., Mayall, M. (Eds.), 2000a. Contourites, Turbidites and Process Interaction. Marine and Petroleum Geology, vol. 17 , pp. 125-342. Special issue

Stow, D.A.V., Mayall, M., 2000 b. Deep-water sedimentary systems: New models for the 21 st century. In: Stow, D.A.V., Mayall, M. (Eds.), Contourites, Turbidites and Process Interaction. Marine and Petroleum Geology, vol. 17, pp. 125-135.

Stow, D.A.V., Piper, D.J.W. (Eds.), 1984a. Fine-grained sediments: Deep-Water Processes and Facies. Gel. Soc. London, Spec. Publ., vol. 15, pp. 1-659.

Stow, D.A.V., Piper, D.J.W., 1984b. Deep-water fine-grained sediments: facies models. In: Stow, D.A.V., Piper, D.J.W. (Eds.), Fine-grained sediments: Deep-Water Processes and Facies. Gel. Soc. London, Spec. Publ., vol. 15, pp. 611-646.

Stow, D.A.V., Shanmugam, G., 1980. Sequence of stuctures in fine-grained turbidites: comparison of recent deep-sea and ancient flysch sediments. Sediment. Geol. 25, 23-42.

Stow, D.A.V., Faugères, J.C., Gonthier, E., 1986. Facies distribution 
and textural variation in Faro Drift contourites: velocity fluctuation and drift growth. Mar. Geol. 72, 71-100.

Stow, D.A.V., Reading, H.G., Collinson, J.C., 1996. Deep Seas. In: Reading, H.G. (Ed.), Sedimentary Environments: Processes, Facies and Stratigraphy, 3rd ed. Blackwell, Oxford, pp. 395-453.

Stow, D.A.V., Faugères, J.C., Viana, A., Gonthier, E., 1998. Fossil contourites: a critical review. In: Stow, D.A.V., Faugères, J.-C. (Eds.), Contourites, Turbidites and Process Interaction. Sediment. Geol., vol. 115, pp. 3-31.

Van Morkhoven, F.P.C.M., Berggren, W.A., Edwards, A.S., 1986. Cenozoic cosmo-politan deep-water benthic foraminifera. Bulletin des Centres de Recherches Exploration-Production ElfAquitaine Mem., vol. 11, pp. 1-423.

Van Veen, G.W., 1969. Geological investigations in the region west of Caravaca, southeastem Spain. Thesis. Univer. Amsterdam. $143 \mathrm{pp}$.

Vera, J.A., 1988. Evolución de los sistemas de depósito en el margen ibérico de la Cordillera Bética.. Rev. Soc. Geol. Esp. 1, 373-391.

Vera, J.A., Molina, J.M., 1999. La Formación Capas Ro jas: caracterización y génesis. Estud. Geol. 55, 45-66.

Vera, J.A., García-Hernández, M., López-Garrido, A.C., Comas, M.C., Ruiz-Ortiz, P.A., Martín-Algarra, A., 1982. El Cretácico de la Cordillera Bética. In: Garcia, A. (Ed.), El Cretácico de España. Universidad Complutense, Madrid, pp. 515-632.

Viana, A.R., Faugères, J.-C., Stow, D.A.V., 1998. Bottom current controlled sand deposits - a review from modern shallow and deep water environments. In: Stow, D.A.V., Faugères, J.-C. (Eds.), Contourites, Turbidites and Process Interaction. Sediment. Geol., vol. 115, pp. 53-80.

Wezel, F.C., 1969. Prossimalita, distalita e analisi dei bacini dei flysch: un punto di vista attualistico. Mem. Soc. Natl. Napoli, Suppl. Boll. 78, 1-12.

Wüst, G., 1936. Schichtung und Zirkulation des Atlantischen -zeans. Das Bodenwasser und die Stratosphäre. Wiss. Ergeb. ber - Dtsch. Atlant. 6, 1-288 (Mete•r 1925-27).

Wüst, G., 1958. Die Stromgeschwindigkeiten und Strommengen in der Atlantischen Tiefsee. Geol. Rundsch. 47, 187-195.

Yokokawa, M., Kishi, M., Masuda, F., Yamanaka, M., 1995. Climbing ripples recording the change of tidal current condition in the Middle Pleistocene Shimosa Group, Japan. In: Fleming, B.W., Bartholomä, A. (Eds.), Tidal Signatures in Modem and Ancient Sediments. International Assoc. Sediment. Spec. Publ., vol. 24. Blackwell Science, Oxford, pp. 301-312. 